\title{
Chemical compositions and antioxidative and antidiabetic properties of underutilized vegetable palm hearts from Plectocomiopsis geminiflora and Eugeissona insignis
}

\begin{abstract}
Underutilized vegetables are currently studied not only for their nutrient values but also for their health-promoting components for protection against chronic diseases. The present study was performed to evaluate chemical compositions and antioxidant properties of underutilized vegetable palm hearts, namely, lalis (Plectocomiopsis geminiflora) and pantu (Eugeissona insignis). Additionally, the vegetable extracts were evaluated for their activities in the inhibition of digestive enzymes and effects on insulin secretion using BRIN BD11 pancreatic cell lines. Both vegetables contain valuable sources of dietary fiber, potassium, and zinc. For the first time, the phenolic compounds of the vegetables were identified and quantified using HPLC-DAD and LC-ESI-MS. Appreciable amounts of chlorogenic acid were found in the studied vegetables. The sample extracts exhibited potential antioxidant capacities through chemical and biological in vitro assays. High inhibition of $\alpha$-amylase activity $(>50 \%)$ was found from the extracts. Thus, it was suggested the vegetable consumption could fulfill the nutrient requirements among local communities.
\end{abstract}

Keyword: Underutilized vegetable; Proximate composition; Phenolic; Antidiabetic;

Plectocomiopsis geminiflora; Eugeissona insignis 